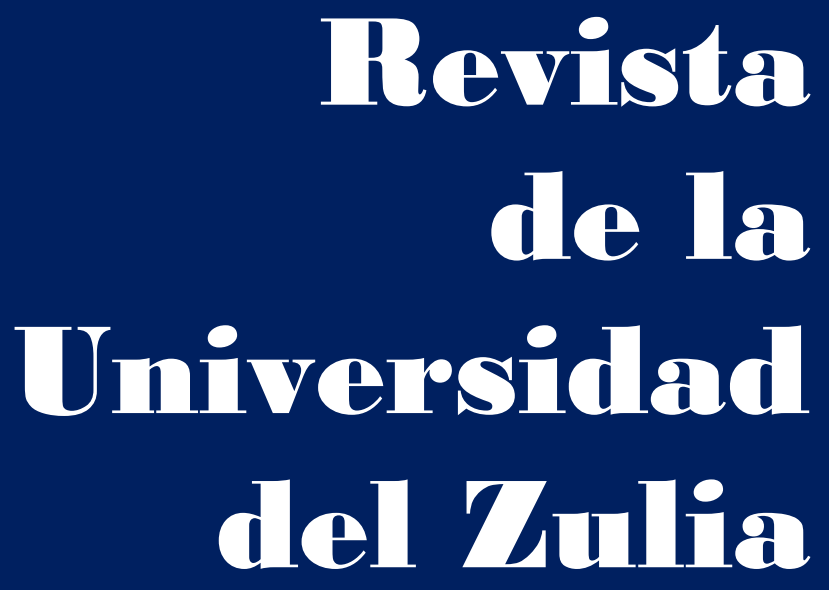

Fundada en 1947

por el Dr. Jesús Enrique Lossada

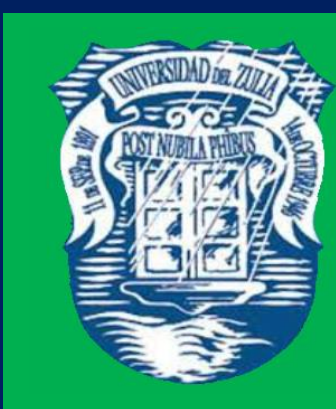

Ciencias del

Agred

Ingemieria

y Teenología
Añต 12 No 32

Enero - Abril 2021

Tercera Época

Maracailbo-Venezuela 


\title{
Simulation of thermal processes on the electrode of a miniature protective spark gap
}

\author{
Igor A. Murog * \\ Valery F. Gnido ** \\ Elena V. Tinina *** \\ Igor A. Ilchuk \\ Tatiana A. Asayeva ***
}

ABSTRACT

The article discusses the issues that arise when determining the temperature in the region of the cathode spot in miniature protective spark gaps. The modeling principle is used to study the temperature field on the spark gap electrode. A mathematical model of the process is compiled on the basis of the balance of power entering the cathode spot and its removal inside the cathode due to thermal conductivity. A numerical solution of the obtained nonlinear heat equation with inhomogeneous boundary conditions by the finitedifference method is presented. The authors compared the found temperatures in the cathode spot for metals of the fourth and fifth groups of the Mendeleev's Periodic Table with the corresponding melting points of the selected metals. A complete correlation was obtained between these temperatures. Simulation of thermal processes in the region of the cathode spot on the electrode made of 42NA-VI alloy has been carried out. The results are presented in the form of diagrams.

KEYWORDS: mathematical modeling, the electrode, electronic device (spark gap), thermal processes, thermal conductivity, cathode spot, metals, temperature, time, energy accumulation.

*Doctor of Technical Sciences, Professor, Director of the Ryazan Institute, Ryazan Institute (branch) of Moscow Polytechnic University Russia, Ryazan. E-mail: alen-pal4@yandex.ru

* Candidate of Technical Science, Assistant professor, Associate Professor, Department of Mechanics and Technology, Ryazan Institute (branch) of Moscow Polytechnic University Russia, Ryazan

*** Candidate of Technical Science, Assistant professor, Associate Professor, Department of Informatics and Information Technology, Ryazan Institute (branch) of Moscow Polytechnic University Russia, Ryazan.

**** Candidate of Technical Science, Assistant professor, Associate Professor, Department of Mechanics and Technology, Ryazan Institute (branch) of Moscow Polytechnic University Russia, Ryazan.

***** Candidate of physical and mathematical Sciences, Assistant professor, head of the Department of Informatics and information technologies, Ryazan Institute (branch) of Moscow Polytechnic University, Russia, Ryazan. 


\section{Simulación de procesos térmicos en el electrodo de una brecha de chispa protectora en miniatura}

RESUMEN

El artículo analiza los problemas que surgen al determinar la temperatura en la región del punto de cátodo en las brechas de chispa protectoras en miniatura. El principio de modelado se utiliza para estudiar el campo de temperatura en el electrodo de separación de chispas. Un modelo matemático del proceso se compila sobre la base del equilibrio de potencia que entra en el punto del cátodo y su eliminación dentro del cátodo debido a la conductividad térmica. Se presenta una solución numérica de la ecuación de calor no lineal obtenida con condiciones límite inhomogéneas por el método de diferencia finita. Los autores compararon las temperaturas encontradas en el punto cátodo para los metales de los grupos cuarto y quinto de la Tabla Periódica de Mendeleev con los correspondientes puntos de fusión de los metales seleccionados. Se obtuvo una correlación completa entre estas temperaturas. Se ha realizado la simulación de procesos térmicos en la región del punto cátodo en el electrodo de aleación 42NA-VI. Los resultados se presentan en forma de diagramas.

PALABRAS CLAVE: modelado matemático, el electrodo, dispositivo electrónico (brecha de chispas), procesos térmicos, conductividad térmica, punto de cátodo, metales, temperatura, tiempo, acumulación de energía.

\section{Introduction}

Miniature uncontrolled spark gaps are widely used in equipment for railway transport and communications (Kiselev, 1988; Anisimov, Belsky, Kiselev and Yashkova, 2001). One of the parameters of the spark gap is the current amplitude in the pulse, which can be on the order of tens of kiloamperes or more, and the pulse duration of tens or more microseconds. The spark gap consists of a ceramic body, two electrodes made of 42NA-VI alloy, and a cathode with a certain emission composition applied to one of these electrodes. The cathode is connected to the electrode by soldering or applied to its surface by vacuum deposition. One of the regularities discovered during the development of spark gaps is that the parameters of the spark gap are significantly affected by the thermal regime of the cathode (Anisimov, and Kiselev, 1990; Anisimov and Kiselev, 1995). This is due to the fact that during the switching process a cathode spot is formed at the cathode of the spark gap: a small brightly luminous region on the cathode surface. The cathode spot has a high temperature, at which the necessary emission from the cathode occurs, which provides the 
REVISTA DE LA UNIVERSIDAD DEL ZULIA. 3ª época. Año 12 N 32, 2021 Igor A. Murog et al. // Simulation of thermal processes on the electrode of miniature... 127-138 DOI: http://dx.doi.org/10.46925//rdluz.32.10

current through the spark gap for the successful protection of equipment against dangerous overvoltages.

Cathode spots appear on the electrodes in all powerful switches. The physical processes occurring in the cathode spot on the electrodes of powerful switches are considered in (Rakhovsky, 1970; Kesaev, 1972).

The physics of current switching in spark gaps does not have experimental data on the temperature in the region of the cathode spot. This is due to a number of reasons. The interelectrode distance in the spark gap is $2 \ldots 5 \mathrm{~mm}$, the current is highly localized, heat is released in a very small volume. In this case, protective spark gaps operate in a single switching mode, the depth of penetration of the thermal field into the electrode during the switching time is less than the thickness of the electrode, therefore, the measurement of the temperature in the region of the cathode spot under such conditions is experimentally difficult.

To analyze the temperature field in the region of the cathode spot, numerical calculation methods can be used, with the help of which analyzes of many physical phenomena are already carried out (Deniskin and Nekrasova, 1982).

When solving problems of non-stationary thermal conductivity, which include the problem of temperature field distribution in the cathode spot region, the method of finite time intervals is widely used (Kalitkin, 1978). This method allows us to build a mathematical model of physical processes in the cathode spot, and modern computer technologies provide a successful solution of these types of problems by conducting temperature estimates in the region with a small volume.

The purpose of this paper is to present the practical application of the finitedifference method for modeling thermal processes occurring in a cathode spot on an electrode made of $42 \mathrm{NA}-\mathrm{VI}$ alloy. The results obtained will contribute to the optimization of existing spark gaps, in which the main cathode is this alloy, as well as the development of new devices with cathodes made of other materials.

The authors simulated thermal processes in the cathode spot on the 42NA-VI alloy electrode in modes that are close in their parameters to the conditions that occur in the cathode spot on the cathode of the spark gap during switching. 
REVISTA DE LA UNIVERSIDAD DEL ZULIA. 3ª época. Año 12 N 32, 2021 Igor A. Murog et al. // Simulation of thermal processes on the electrode of miniature... 127-138 DOI: http://dx.doi.org/10.46925//rdluz.32.10

\section{Basic relations}

A cathode spot is formed on the electrode under the action of a high-intensity heat flux. The temperature in the region of the cathode spot can reach the melting temperature of the electrode material and higher. Let us assume that the main process determining heat loss in the cathode spot is its removal into the electrode due to thermal conductivity.

To find the temperature field at the cathode, it is necessary to solve the nonlinear equation of heat conduction with inhomogeneous boundary conditions.

The scheme for calculating the thermal regime in the region of the cathode spot is shown in Figure 1.

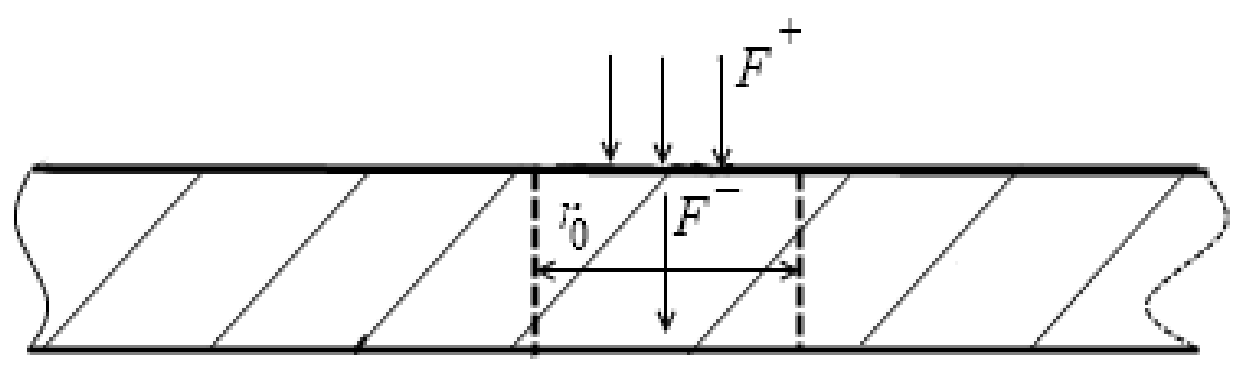

Figure 1. Scheme for calculating the thermal regime in the area of the cathode spot: $\mathrm{F}^{+}$ is falling heat flux; $F^{-}$is the heat flux that removes heat from the cathode spot into the cathode; $r_{0}$ is the radius of the cathode spot

Let us assume that the conditions for the propagation of heat in the electrode have cylindrical symmetry; therefore, the initial expression describing the conditions for the propagation of heat through the thickness of the electrode for the unsteady mode can be written as follows

$$
\frac{\partial T}{\partial t}=a\left(\frac{1}{r} \frac{\partial T}{\partial r}+\frac{\partial^{2} T}{\partial r^{2}}+\frac{\partial^{2} T}{\partial z^{2}}\right)
$$

where $T$ is the temperature at this point;

$r$ is the radius measured from the center of the cathode spot;

$z$ is coordinate in the direction perpendicular to the cathode plane;

$t$ is the time counted from the moment of the cathode spot formation.

Here $a=\frac{\lambda}{c_{T} \rho}$ is the thermal diffusivity; $\lambda$ is coefficient of thermal conductivity; $c_{T}$ is the heat capacity coefficient; $\rho$ is the density of the substance.

To calculate the temperature field using the finite-difference method, equation (l) can be represented in the form [8]. 


$$
T_{i, j, k}=a\left(T_{i, j, k}\right) \Delta t\left(\frac{1}{j h} \frac{T_{i, j+1, k}-T_{i, j, k}}{h}+\frac{T_{i, j-1, k}-2 T_{i, j, k}+T_{i, j-1, k}}{h^{2}}+\frac{T_{i, j, k+1}-2 T_{i, j, k}+T_{i, j, k-1}}{h}\right)+T_{i, j, k} .
$$

Here $t$ is time, $j$ is the temperature distribution along the radius, $k$ is the temperature distribution along the electrode depth. To calculate temperatures by expression (2), a program has been developed. Variables that determine the state of the parameters of the mathematical model were introduced into the program: the number of iterations that determine the duration of the modeling process, the power of the heat flux released in the cathode spot, the radius of the cathode spot, the initial temperature, the values of the heat capacity coefficients $c_{\mathrm{T}}$, the density of the cathode material $\rho$, and the thermal conductivity $\lambda$.

\section{Simulation results and their discussion}

First, let us estimate the temperature of the cathode spot on electrodes made of different metals. The thermophysical properties of the electrode material depend on temperature. First of all, this concerns the coefficient of thermal conductivity: with an increase in temperature, its value decreases.

The thermal conductivity coefficient for most metals decreases in the first approximation according to a linear law when the temperature changes from $0{ }^{\circ} \mathrm{C} C$ to the melting point. In the range of several hundred degrees, changes in the thermal conductivity are of the order of $10 \%$. Therefore, the maximum temperature in the cathode spot during the simulation will be set to no more than $400{ }^{\circ} \mathrm{C}$.

Table 1 shows the metals of the fourth and fifth groups of the Mendeleev's Periodic Table, for which the temperature of the cathode spot was estimated. Simulation parameters: the duration of the heat flow is $500 \mu \mathrm{s}$, the power of the heat flow is $1200 \mathrm{~W}$. The third column of Table 1 shows the values of the melting temperatures of these metals. It was found that the values of the cathode spot temperature decrease monotonically with an increase in the ordinal number of metals. The metals are arranged in the same sequence according to the melting point. 
REVISTA DE LA UNIVERSIDAD DEL ZULIA. 3ª época. Año 12 N 32, 2021

Igor A. Murog et al. // Simulation of thermal processes on the electrode of miniature... 127-138

DOI: http://dx.doi.org/10.46925//rdluz.32.10

This pattern is determined by the peculiarities of the formation of the heatconducting properties of metals.

Table 1. Comparison of cathode spot temperatures and melting temperatures for different materials

\begin{tabular}{|l|c|c|}
\hline Material & $\begin{array}{l}\text { Cathode spot temperature, } \\
{ }^{\circ} \mathrm{C}\end{array}$ & Melting temperature, ${ }^{\circ} \mathrm{C}$ \\
\hline Iron & 370 & 1535 \\
\hline Cobalt & 355 & 1490 \\
\hline Nickel & 335 & 1445 \\
\hline Copper & 315 & 1083 \\
\hline Silver & 290 & 960 \\
\hline
\end{tabular}

As is known (Kalitkin, 1978) heat transfer in metals is carried out by electron $\lambda_{e}$ and phonon $\lambda_{\phi}$ thermal conductivity. With electronic thermal conductivity, energy transfer is carried out by conduction electrons, with phonon thermal conductivity - by lattice vibrations. In accordance with the quantum model of a solid for pure metals, the ratio of electronic and phonon thermal conductivity is about 100. Therefore, in most cases, it can be assumed that heat transfer for metals is due to the electronic component of thermal conductivity.

The electronic thermal conductivity is determined (Worth and Thomson, 1966).

$$
\lambda_{e}=-\frac{\kappa^{2} T n v_{f} l}{E_{f}} .
$$

Here: $n$ is the number of free electrons in a unit volume; $\kappa$ is Boltzmann's constant; $l$ is the average free path; $T$ is the temperature; $E_{f}$ is the Fermi energy; $v_{f}$ is the speed of electrons with Fermi energy.

As follows from equation (3), the electronic component of thermal conductivity is proportional to the number of free electrons - conduction electrons. At the same time, the number of conduction electrons is determined by the position of the atom in the Mendeleev's Periodic Table. A gradual increase in conduction electrons from iron to copper 
REVISTA DE LA UNIVERSIDAD DEL ZULIA. 3ª época. Año 12 N 32, 2021 Igor A. Murog et al. // Simulation of thermal processes on the electrode of miniature... 127-138

DOI: http://dx.doi.org/10.46925//rdluz.32.10

and silver leads to an increase in the $\lambda_{e}$ coefficient and, accordingly, to a decrease in the temperature on the surface of the cathode spot.

The obtained connection between the temperatures testifies to the correctness of the constructed model and the possibility of its use for studying thermal processes at the electrodes of spark gaps made of different metals, including alloys.

Let us consider the kinetics of the temperature field on an electrode made of 42NAVI alloy, which, as already mentioned earlier, is widely used in protective miniature spark gaps. The values of the parameters used in the simulation are shown in Table 2.

Table 2. Values of parameters used in modeling

\begin{tabular}{|c|c|c|c|}
\hline Parameter & Designation & Dimension & $42 \mathrm{NA}-\mathrm{VI}$ \\
\hline $\begin{array}{c}\text { Thermal } \\
\text { conductivity }\end{array}$ & $\lambda$ & $\mathrm{cal} /(\mathrm{cm} \cdot \mathrm{s} \cdot \mathrm{K})$ & $0,1 \mathrm{l}$ \\
\hline Density & $\rho$ & $\mathrm{cal} /(\mathrm{cm} \cdot \mathrm{s} \cdot \mathrm{K})$ & 8,2 \\
\hline Heat capacity & $c$ & $\mathrm{cal} /(\mathrm{cm} \cdot \mathrm{s} \cdot \mathrm{K})$ & 0,5 \\
\hline $\begin{array}{c}\text { Melting } \\
\text { temperature }\end{array}$ & $T$ & ${ }^{0} \mathrm{C}$ & 1723 \\
$\mathrm{~K}$ & 1996 \\
\hline
\end{tabular}

The dimensions of the electrode corresponded to the real geometry of the miniature protective spark gap. The electrode surface, which limits the working area of the device, has a diameter of $6 \mathrm{~mm}$, and the electrode thickness is $1.5 \mathrm{~mm}$. We assume that a cathode spot is formed on the electrode under the action of a power pulse.

The diagram of the distribution of the temperature field in the region of the cathode spot is shown in Figure 2. "n" along the axes in the figures is the number of steps in the program array. One step in " $\mathrm{n}$ " is $33 \mu \mathrm{m}$. The calculated field in the program is $30 \mathrm{n}$ by $70 \mathrm{n}$.

The simulation was carried out under the following conditions: the pulse duration was $500 \mu \mathrm{s}$, the pulse power was $180 \mathrm{~W}$. Figure 2 shows the temperature field displayed after $100 \mu \mathrm{s}$ from the moment of the pulse application. Similar diagrams were obtained after 300 and $500 \mu$ s, respectively. Since the heat flux removed due to thermal conductivity 


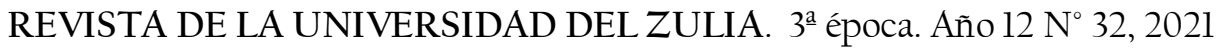

Igor A. Murog et al. // Simulation of thermal processes on the electrode of miniature... 127-138

DOI: http://dx.doi.org/10.46925//rdluz.32.10

inside the cathode is less than the flux entering the cathode spot, there is a rise in temperature in the region of the cathode spot. During the simulation, it was found that the temperature of the cathode spot during a time of $100 \mu$ s changes from room temperature of $293 \mathrm{~K}$ to a value of about $520 \mathrm{~K}$. At subsequent moments of time, it rises to $630 \mathrm{~K}$ after 300 $\mu$ s and to $680 \mathrm{~K}$ after $500 \mu$ s, respectively.

The temperature rise, in comparison with the boundaries of the computational domain, at the selected times are also different. Heat entering the cathode spot, due to thermal conductivity, is removed inside the electrode, gradually increasing its temperature. If the excess of $293 \mathrm{~K}$ at the boundary of the computational domain relative to room temperature is practically absent at a time instant of $100 \mu$ s, then after $300 \mu \mathrm{s}$ the excess is about $80 \mathrm{~K}$, and after $500 \mu$ s it reaches $150 \mathrm{~K}$.

The temperature field inside the electrode is a concentric semicircle. With distance from the surface of the cathode spot, the temperature gradually decreases; therefore, the isotherms are semicircles with an increasing radius. The temperature over the surface of the cathode spot will be variable. The largest value is observed in the center of the cathode spot: the isotherm radius is minimal.

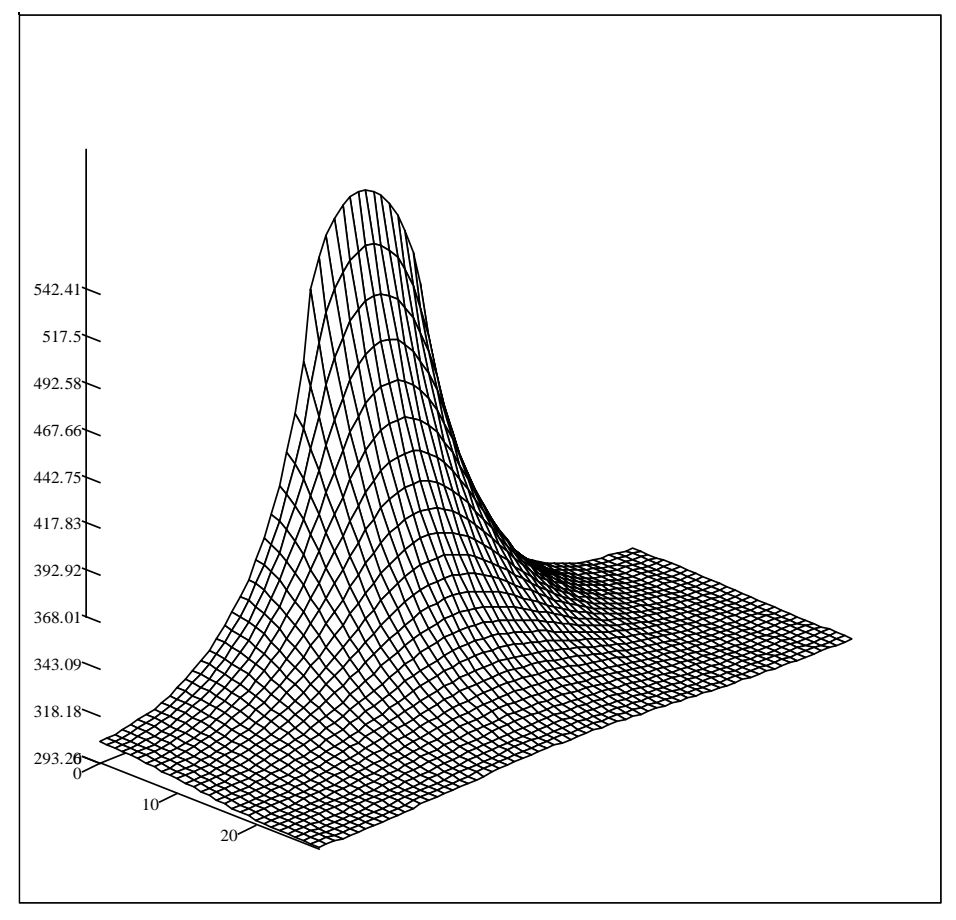

Figure 2. The temperature field under the influence of a heat flux with a duration of $500 \mu \mathrm{s}$ and a power of $180 \mathrm{~W}$ at a time of $100 \mu \mathrm{s}$ 


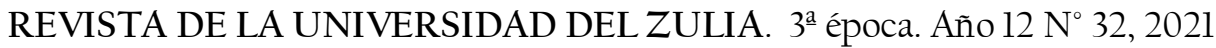

Igor A. Murog et al. // Simulation of thermal processes on the electrode of miniature... 127-138

DOI: http://dx.doi.org/10.46925//rdluz.32.10

The temperature fields were calculated for various modes. The main condition in the simulation was chosen so that at a given power supplied to the cathode, phase changes in the cathode material did not occur. The simulation results for a pulse power of $P=3300 \mathrm{~W}$ with different pulse durations are shown in Figure 3.

The data were obtained: Figure 3, a - the duration of the heat flux 244 ns, Figure 3, b $-4.2 \mu \mathrm{s}$. An increase in the pulse power to $3300 \mathrm{~W}$ causes a sharp rise in temperature in the region of the cathode spot.

With a pulse duration of $244 \mathrm{~ns}$, the temperature reaches $900 \mathrm{~K}$, and with a duration of $4.2 \mu \mathrm{s}$, it is already close to the melting temperature. At the same time, the depth of heat propagation inside the electrode during the pulse action significantly decreases, which follows from a comparison of the results presented in Figures 2 and 3. The excess of the temperature of the cathode spot in relation to the "cold" part of the electrode is about 1426 K (Figure 3, b).

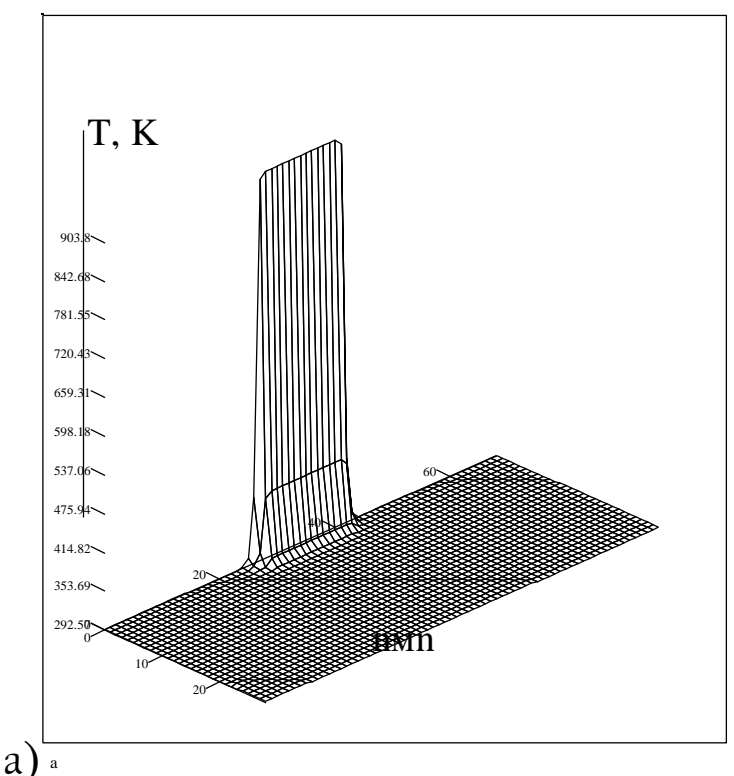

Figure 3. Temperature fields in the cathode spot region at a pulse power $P=3300 \mathrm{~W}$ and for different pulse durations:
a) $244 \mathrm{~ns}$; b) $4.2 \mu \mathrm{s}$

The temperature fields for different points in time during the cooling process are shown in Figure 4. The simulation results correspond to the case with a pulse duration of $4.2 \mu$ s. Since a small amount of heat accumulates in the cathode spot during the pulse duration, cooling occurs almost instantaneously. During $8 \mu \mathrm{s}$, the temperature of the 
REVISTA DE LA UNIVERSIDAD DEL ZULIA. 3ª época. Año 12 N 32, 2021 Igor A. Murog et al. // Simulation of thermal processes on the electrode of miniature... 127-138

DOI: http://dx.doi.org/10.46925//rdluz.32.10

cathode spot decreases almost twice and is about $770 \mathrm{~K}$ (Figure 4, a). Subsequently, the cooling rate slows down. After $31 \mu \mathrm{s}$, counted from the moment the pulse is removed, the surface of the cathode spot is cooled to a temperature of about $450 \mathrm{~K}$ (Figure 4, b). At subsequent moments in time, due to the process of thermal conductivity, the heat further spreads in the electrode material, increasing the temperature in it within the calculated region (Figure 4, c). The limiting distribution of the calculated temperature field (at the moment of time $100 \mu \mathrm{s})$ is shown in Figure 4, d. The temperature at the boundary of the computational domain is about $315 \mathrm{~K}$.

Therefore, with an increase in the heat flux power, the arising high-temperature field in the region of the cathode spot will penetrate less and less deep into the electrode, being within a few micrometers on the electrode surface. This shows that the thickness of the cathodes, which are deposited on the electrode, can be several micrometers. The practice of developing cathodes for miniature protective spark gaps confirms the found patterns.

It is known that in real designs of protective miniature spark gaps, materials with a high emissivity are applied to the 42NA-VI alloy electrode (Anisimov, 1966; Kiselev, Gnido, Anisimov and Tinina, 2001). Cathodes made of these materials have a low work function, which ensures a low arc maintenance voltage in the device during switching, and, accordingly, reduces the power released on the electrode as a whole. In this case, the thickness of the cathodes is a few micrometers. This, as studies have shown, was sufficient to stabilize the parameters during operation (Kiselev, Gnido, Anisimov and Tinina, 2001). The erosion zone at the cathode is within 1 ... 1.5 microns. These values correspond in order of magnitude to the dimensions of the high-temperature field obtained on the 42NA-VI electrode during simulation.

\section{Conclusion}

Modeling the temperature field on electrodes made of metals of the fourth and fifth groups of the Mendeleev's Periodic Table showed a complete correlation in the temperature of the cathode spot and the melting temperature of metals. The results show that with an increase in the serial number of the element, the temperature of the cathode spot decreases: from iron to copper and silver. 


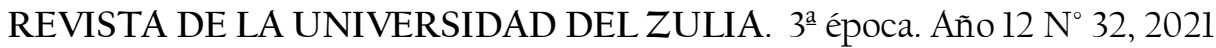

Igor A. Murog et al. // Simulation of thermal processes on the electrode of miniature... 127-138

DOI: http://dx.doi.org/10.46925//rdluz.32.10

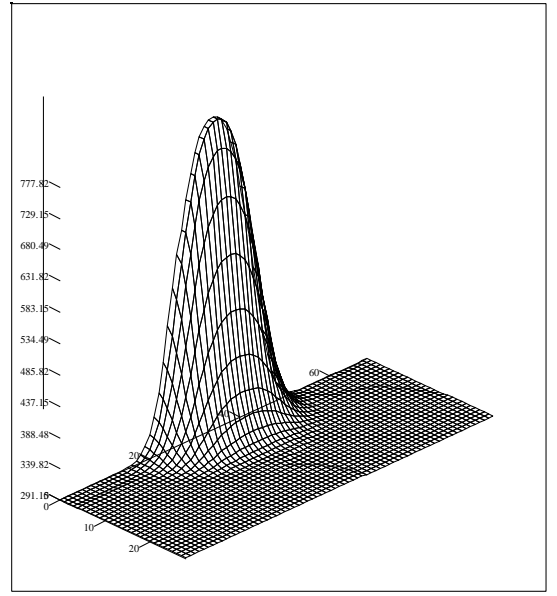

a)

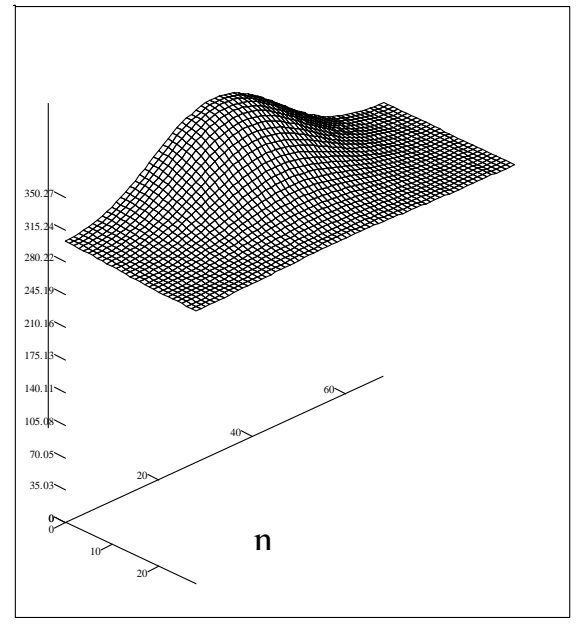

c)

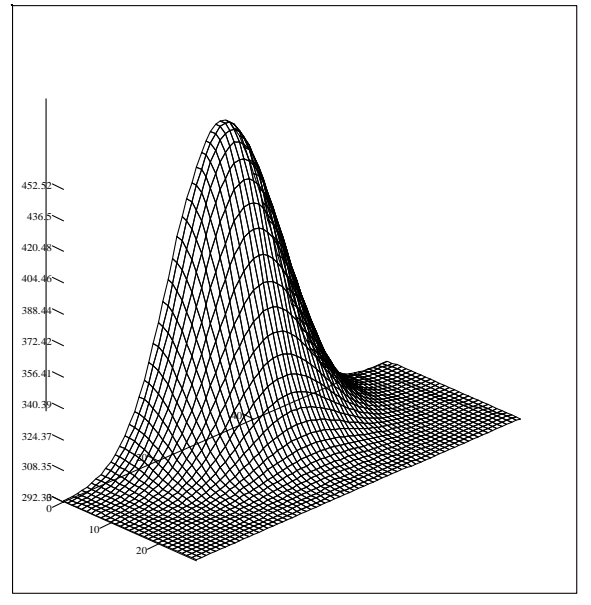

b)

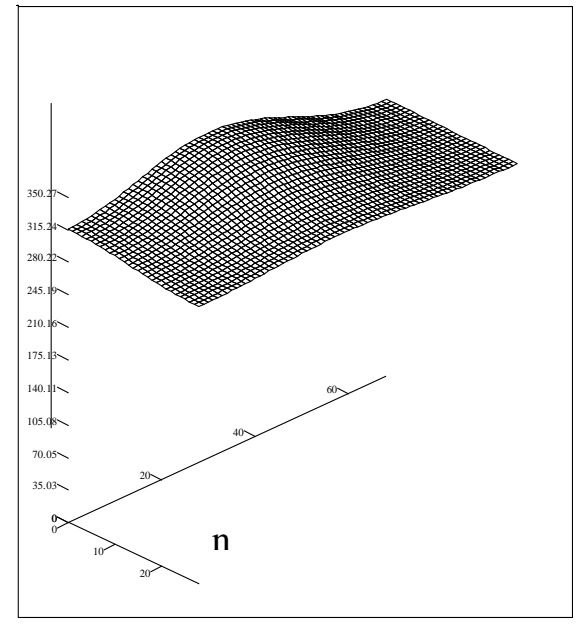

d)

Figure 4. Fields of cathode temperatures during cooling at different times: a) $8 \mu \mathrm{s}$; b) $31 \mu \mathrm{sc}) 60 \mu \mathrm{s} d) 100 \mu \mathrm{s}$

Numerical modeling of the kinetics of the temperature field on the electrode made of 42NA-VI alloy made it possible to establish:

1. Under conditions of powerful heat flux, the temperature of the cathode spot can reach the melting temperature.

2. The time of energy accumulation in the region of the cathode spot, when its surface reaches the melting temperature, is microseconds.

3. The thickness of the high-temperature field in the region of the cathode spot during the time of the heat flux can be micrometers.

It is shown that with the help of modeling, taking into account heat losses in the cathode spot only due to thermal conductivity, results can be obtained that sufficiently 


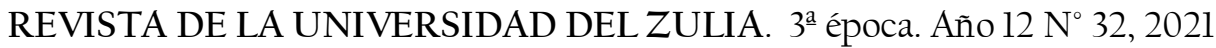

Igor A. Murog et al. // Simulation of thermal processes on the electrode of miniature... 127-138

DOI: http://dx.doi.org/10.46925//rdluz.32.10

fully determine the thermal regime in the cathode spot, when in the studied range of heat flow power, material erosion will practically not occur or will be minimal.

In order to further study the process of erosion of the cathode material in spark gaps, it is necessary to further study and model the temperature field, taking into account the heat losses due to evaporation and melting, which can actually be observed in the cathode spot of the spark gap.

\section{References}

Anisimov V.F. (1996). Thin-film cathodes for high-current hydraulic fracturing. All-Russian Symposium on Emission Electronics. Ryazan, p. 116.

Anisimov V.F., Belsky D.P. Kiselev Yu.V. and Yashkova V.M. (2001). Uncontrolled gas-filled arresters and prospects for their development. Electronics. Interuniversity collection. Ryazan: RGRTA, pp. 28-32.

Anisimov V.F., Kiselev Yu.V. (1990). Processes on the cathodes of uncontrolled gas-filled spark gaps at high current loads. XXI All-Union Conference on Emission Electronics. Vol. l. Leningrad, p. 57.

Anisimov V.F., Kiselev Yu.V. (1995). Investigation of erosion processes on hydraulic fracturing electrodes. Vacuum and Plasma Electronics. Interuniversity collection of scientific papers. Ryazan, 73 p.

Deniskin Yu.D., Nekrasova I.F. (1982). Application of the modeling method for solving problems of thermal conductivity in electronic devices. Moscow: Mir, $84 \mathrm{p}$.

Kalitkin N.N. (1978). Numerical methods. Science, 512 p.

Kesaev I.G. (1972). Cathodic processes of an electric arc. Moscow: Atomizdat, p. 304.

Kiselev Yu.V. (1988). Prospects for the development of spark gaps to protect equipment and communication lines from hazardous overvoltages. Interuniversity subject collection of scientific papers. Omsk: Omsk Institute of Railway Engineers, p. 14-19.

Kiselev Yu.V., Gnido V.F., Anisimov V.F., Tinina E.V. (2001). Development and research of materials for cathodes of protective spark gaps. Ryazan, Vestnik RGRTA, no. 9, p. 118-121.

Rakhovsky V.I. (1970). Physical foundations of electric current commutation in vacuum. Moscow: Nauka, p. 536.

Worth Ch., Thomson R. (1966). Solid State Physics. Translated from English edited by S.V. Tyablikova. Moscow: Mir, 567 p. 